\title{
Current situation analysis of diabetic home care patients
}

\author{
(D) Meltem Sertbas, ${ }^{1}$ (D) Ozlem Guduk, ${ }^{1}$ (D) Ozden Guduk, ${ }^{2}$ () Zeynep Yazici, ${ }^{3}$ () Selma Dagci, ${ }^{4}$ \\ Yasar Sertbas ${ }^{1}$ \\ ${ }^{1}$ Department of Internal Medicine, Health Sciences University Fatih Sultan Mehmet Training and Research Hospital, Istanbul, Turkey \\ ${ }^{2}$ Health Institutes of Turkey, Istanbul, Turkey \\ 3Department of Cardiology, Siyami Ersek Training and Research Hospital, Istanbul, Turkey \\ ${ }^{4}$ Department of Internal Medicine, Health Sciences University, Umraniye Training and Research Hospital, Istanbul, Turkey
}

\begin{abstract}
OBJECTIVE: Diabetes is one of the primary diagnoses for admission to home health care units. Although there are many studies about elderly diabetic patients, there are not many studies on home care patients with diabetes. The present study aims to analyze the current status of diabetic home care patients with their biochemical data and medications.

METHODS: This was a retrospective study, including 256 diabetic patients who were following up by the Home Health Unit of Istanbul Provincial Health Directorate Public Hospitals Services-2. In this study, we analyzed the current biochemical data of the patients with their medications.

RESULTS: In this study, 185 female (72.3\%) and 71 male $(27.7 \%)$ patients were recruited with the mean $\mathrm{HbA1c}$ of $8.25 \pm 1.77$. Among these patients, $65 \%$ of them were using oral antidiabetic (OAD), and $58 \%$ were using insulin. There were $21(8.2 \%)$ patients who were not receiving any treatment. While patients who were using only oral antidiabetic have better A1c levels (A1c: $7.73 \pm 1.45$ ), patients who were insülin using had HbA1c levels as high as the patients who were not using any medication. This may be due to the progression of diabetes, fear of hypoglycemia or insufficient insülin use. While metformin was the most commonly used OAD, with a $38 \%$ usage rate. When compared to HbA1c levels, there was no difference between the types of insulin used $(p=0.167)$.

CONCLUSION: As a result, it is important to plan regular visits and personalized treatment by keeping in mind the benefits to risk ratios in home-care diabetic patients.

Keywords: Antidiabetics; diabetes mellitus; home care services.

Cite this article as: Sertbas M, Guduk O, Guduk O, Yazici Z, Dagci S, Sertbas Y. Current situation analysis of diabetic home care patients. North Clin Istanb 2020;7(2):140-145.
\end{abstract}

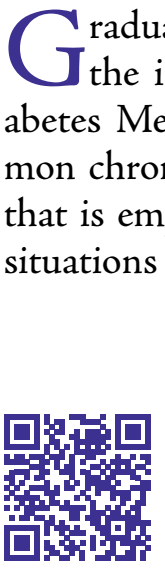

Received: October 03, 2019 Accepted: October 22, 2019 Online: October 25, 2019 Ic Hastaliklari Anabilim Dali, Istanbul, Turkey.

Tel: +90532 3000028 e-mail: yserzincan24@gmail.com

(c) Copyright 2020 by Istanbul Provincial Directorate of Health - Available online at www.northclinist.com den that countries put on the health systems $[2,3]$. The global diabetes burden has increased significantly in recent years and is expected to affect more than 642 million adults by 2040 [4]. According to the American Diabetes Association 2018, the high prevalence of Diabetes Mellitus by $25 \%$ and prediabetes by $50 \%$ in a population over

Correspondence: Dr. Yasar SERTBAS. Saglik Bilimleri Universitesi, Fatih Sultan Mehmet Egitim ve Arastirma Hastanesi, 
65 years old is further increasing the importance of DM $[5,6]$. In addition to the increasing incidence of diabetes in developing countries, studies predict that the number of patients with diabetes will be twice as high in the near future, especially among people over 60 years of age [7].

To provide more efficient health care services to the elderly population, legislation related to the execution of home health services in Turkey published by the Ministry of Health has been launched with the document number 3895 on February $1^{\text {st }}$, 2010. In the scope of the directive, home health services include the provision of medical care and rehabilitation of bed-dependent patients with specialized staff within the home and family environment of the person instead of the health institutions and organizations. In this sense, patients' treatment follow-ups, necessary examinations, the provision of medical care and rehabilitation services, and the provision of oral and dental health services will be performed by the home health units [8].

The use of home health services is increasing concerning providing services to patients with mobilization problems in a comfortable environment, protecting the patient from hospital infections and preventing unnecessary hospitalizations. Diabetes, as the primary diagnosis for admission to home health care, is located just behind cerebrovascular events or heart failure. It is the leading diagnosis with the combination of primary and secondary diagnoses [9-11]. Although there are many studies about elderly diabetic patients in the literature, there is not enough specific study of home care patients with diabetes. The present study aims to analyze the current status of diabetic home care patients with their biochemical data and medications.

\section{MATERIALS AND METHODS}

In this study, we recruited the patients, who were visited by the Home Health Unit, which operates within the scope of Istanbul Provincial Health Directorate Public Hospitals Services-2, between January 01 and December 31,2018 . The patients' information was retrospectively scanned from the database and a totally 256 diabetic patients who were examined for blood sugar monitoring were included in this study.

The present study was carried out in accordance with the ethical principles that had their origin in the Declaration of Helsinki and approved by the Ethics Committee of the Fatih Sultan Mehmet Training and Research Hospital (FSMEAH- 28.3.2019-42).

\section{Statistical Analysis}

All analyses were performed using the statistical package for the social sciences (SPSS) program version 22.0 for Windows. The results of all parameters belonging to patients were given as mean \pm standard deviation. The 1-sample Kolmogorov-Smirnov test was used to assess the distribution of the data. Numerical variables of more than two different groups were compared using either the one-way Anova test or Kruskal Walles due to their distributions. Categorical variables were analyzed by the $\chi^{2}$ test. Probability values were 2 -tailed, and a P-value of less than 0.05 was considered significant.

\section{RESULTS}

In this study, we recruited 185 female (72.3\%), 71 male $(27.7 \%)$ patients with the mean age of $79.8 \pm 10.2$. Table 1 presents the demographic data and biochemical parameters of the patients.

TABLE 1. Demographic and biochemical parameters of the patients

\begin{tabular}{lcc} 
& Mean & SD \\
\hline Age (year) & 79.78 & 10.2 \\
Glycolized hemoglobin (HbA1c) & 8.25 & 1.77 \\
Total cholesterol $(\mathrm{mg} / \mathrm{dl})$ & 185.34 & 46.627 \\
HDL cholesterol $(\mathrm{mg} / \mathrm{dl})$ & 41.38 & 11.53 \\
LDL - cholesterol $(\mathrm{mg} / \mathrm{dl})$ & 122.02 & 95.560 \\
Triglyceride $(\mathrm{mg} / \mathrm{dl})$ & 141.60 & 58.432
\end{tabular}

SD: Standard deviation; HDL: High density lipoprotein; LDL: Low density lipoprotein.

TABLE 2. Effects of the diabetic drug groups on blood sugar regulation

\begin{tabular}{|c|c|c|c|c|}
\hline \multirow[b]{2}{*}{$\begin{array}{l}\text { Classification according } \\
\text { to drug usage }\end{array}$} & \multirow[b]{2}{*}{$\mathrm{n}$} & \multicolumn{2}{|c|}{$\begin{array}{l}\text { Glycolized } \\
\text { Hemoglobin } \\
\text { (HbA1c) }\end{array}$} & \multirow[b]{2}{*}{$\mathrm{p}$} \\
\hline & & Mean & SD & \\
\hline Only insulin usage & 69 & 8.46 & 1.60 & 0.01 \\
\hline Insulin + OAD usage & 79 & 8.54 & 2.07 & \\
\hline Only OAD usage & 87 & 7.73 & 1.45 & \\
\hline No antidiabetic drug usage & 21 & 8.56 & 1.95 & \\
\hline
\end{tabular}

SD: Standard deviation; OAD: Oral antidiabetic drug. 
When the patients were classified according to the drugs they used, it was seen that $65 \%$ of the patients were using oral antidiabetic (OAD), and $58 \%$ were using insulin. $21(8.2 \%)$ patients were not receiving any treatment. In Table 2 , patients were divided into four different groups according to their diabetic drug usage. $\mathrm{Pa}$ tients who were using only OAD had better blood sugar regulation than other groups. On the other hand, blood glucose levels were higher in patients using insulin (alone or in combination with OAD). They were even as high as the results of patients who were not using any medication $(p>0.05)$.

In this study, $65 \%(n=166)$ of the patients were using OAD, and Table 3 shows the usage of Oral Andi-diabetics, according to their classes. Metformin was the most commonly used OAD with a $39 \%$ utilization rate.

TABLE 3. Use of the oral anti-diabetics, according to their classes

\begin{tabular}{lcc} 
Oral Anti-diabetic & $\mathrm{n}$ & $\%$ \\
\hline Metformin & 101 & 39 \\
Insulin Secretagogues & 61 & 24 \\
Thiazolidinediones & 6 & 2 \\
Oral dipeptidyl peptidase 4 inhibitors & 64 & 25 \\
Glucagon-like peptide 1 receptor agonists & 2 & 0.7 \\
Sodium-Glucose Cotransporter 2 & & \\
Inhibitors & 12 & 5 \\
Alpha glucosidase inhibitors & 12 & 5 \\
\hline
\end{tabular}

$\%=(n / 256)$.

TABLE 4. Types of the insulin use and their relationship with HbA1c

\begin{tabular}{|c|c|c|c|c|c|}
\hline \multirow[b]{2}{*}{$\begin{array}{l}\text { Classification of insulin } \\
\text { usage }\end{array}$} & \multirow[b]{2}{*}{$\mathrm{n}$} & \multirow[b]{2}{*}{$\%$} & \multicolumn{2}{|c|}{$\begin{array}{l}\text { Glycolized } \\
\text { Hemoglobin } \\
\text { (HbA1c) }\end{array}$} & \multirow[b]{2}{*}{$\mathrm{p}$} \\
\hline & & & Mean & SD & \\
\hline Long acting insulin use & 55 & 21 & 8.14 & 1.62 & 0.167 \\
\hline $\begin{array}{l}\text { Long + short acting } \\
\text { (intensive usage) }\end{array}$ & 56 & 22 & 8.79 & 2.17 & \\
\hline Mixt insulin usage & 36 & 14 & 8.61 & 1.63 & \\
\hline
\end{tabular}

SD: standard deviation.
In total, $58 \%(n=148)$ of the patients were using insulin, and there was no statistically significant difference between them concerning long-acting, intensive (long and short-acting) and mixed insulin usage ( $p>0.05)$ (Table 4).

Although many studies have been conducted with elderly diabetic patients previously, there are only few studies related to bed-dependent diabetic home health patients in the literature. In this study, we investigated demographic data, drug usage and their effects on $\mathrm{HbA1c}$ levels in diabetic patients being followed up in the context of home health services.

\section{DISCUSSION}

American Diabetes Association (ADA) recommends that the A1c test should be performed at least two times a year in patients who are meeting treatment goals and quarterly in patients without glycemic control [12]. According to ADA recommendations, the $\mathrm{HbA} 1 \mathrm{c}$ target is $<6.5 \%$ in young adults without risk of hypoglycemia, whereas it is $<8 \%$ in patients with complications at risk of hypoglycemia or with limited life expectancy [12]. ADA also established new goals for $\mathrm{HbA} 1 \mathrm{c}$ for older diabetic patients in 2019. Older adults with few coexisting chronic illnesses and intact cognitive function were recommended to have lower glycemic goals as $\mathrm{HbA1c}$ $<7.5 \%(58 \mathrm{mmol} / \mathrm{Mol})$, while the patients with multiple coexisting chronic illnesses and cognitive impairment recommended to have less stringent glycemic goals like HbA1c $<8.0-8.5 \%$ (64-69 mmol/Mol) [13]. In different studies, it has also demonstrated that the best survival was presented in old diabetic patients with $\mathrm{HbA} 1 \mathrm{c}$ levels between 7.0 to $8.0 \%[14,15]$. In some guidelines, the target $\mathrm{HbA} 1 \mathrm{c}$ levels were determined according to fragility index or functional dependence, like $\mathrm{HbA} 1 \mathrm{c}$ targets were taken $<8.5$ for patients with higher fragility index (index: 6-8) or dementia [16, 17]. According to our observations, home care diabetic patients in Turkey have $\mathrm{HbA} 1 \mathrm{c}$ levels $8.25 \pm 1.77 \%$, which seems to be in the target values of guidelines.

Although many studies have been conducted regarding the efficacy and indications of diabetes medications, there are not so many studies about the distribution of drugs used by home care diabetic patients. In some of these studies, in addition to mostly used oral antidiabetic agents, the insulin usage rates were ranging between $20 \%$ $-30 \%[18,19]$. In our study, the rate of oral antidiabetic use was $65 \%$, while the rate of insulin use was $58 \%(30 \%$ 
only insulin use and $28 \%$ for insulin + OAD). In our study, excessive insulin use can be explained with a higher age, more complications and higher diabetes duration of home care patients, unlike other studies. In this study, the patients using only OAD had better blood glucose regulation than other groups $(\mathrm{p}<0.05)$. On the other hand, blood glucose levels were higher in patients using insulin (alone or in combination with OAD), and even it was as high as in the patients who did not use any medication $(p>0.05)$. In our opinion, the reason for the high HbA1c levels may be due to the progression of diabetes, insufficient use of insulin, or fear of hypoglycemia of patients.

In accordance with the literature, in our study, $65 \%$ of the patients were using OAD. In the literature, metformin was presented as a first-line treatment option for elderly diabetics as in young adults $[13,20-22]$. Metformin can be safely used by diabetic patients with glomerular filtration rate $>30 \mathrm{ml} / \mathrm{min} / 1.73 \mathrm{~m}^{2}$. It improves peripheral insulin sensitivity and decreases hepatic glucose output $[23,24]$. The most common side effects of the metformin are nausea, vomiting, abdominal discomfort and diarrhea [25]. Although clinical studies have shown that only 5\% of the subjects discontinue metformin due to gastrointestinal symptoms, this may be particularly worrying in the frail elderly population with poor appetite and low daily low-calorie intake. Vitamin B12 deficiency should also be considered in long term use [26]. Although it is rare, metformin associated lactic acidosis (MALA) is another fatal complication, which occurs more frequently in elderly patients with renal impairment [25]. In our study, even though the majority of the patients used metformin (39\%), this rate was lower than other studies. This was attributed to that older patients were less tolerant of metformin (GIS intolerance) and had more renal and cardiovascular complications.

Thiazolidinediones (TZDs) are the second class of insulin sensitizers. They reduce insulin resistance in peripheral tissue and also decrease hepatic gluconeogenesis [21]. Since TZDs do not cause hypoglycemia and can be administered to the patients with renal failure, they may be thought to be an alternative medication for the treatment of DM. Apart from these good aspects, their use was drastically limited in the past years due to concerns about worsening heart failure due to fluid retention [27], decreased bone density [28], and increased risk of bladder cancer [29]. Thus, use in older patients with underlying bone disease, family history of cancer and heart disease could potentially be problematic. In our observation, $2 \%$ of home care patients were using these drugs and we thought that they would be used as a second-line option for patients who have not achieved their glycemic targets on alternative therapies (metformin, sulfonylureas, insulin).

Dipeptidyl peptidase-4 (DPP-4) inhibitors are responsible for preventing the degradation of incretins, mainly glucose-dependent insulinotropic polypeptide (GIP) and glucagon-like peptide-1 (GLP1). They reduce blood glucose concentration by increasing insulin synthesis and decreasing glucagon production [30]. However, it is important to be careful about reported side effects as pancreatitis [31], nasopharyngitis [32] and heart failure [33]. In case of severe renal impairment, dose adjustment should be considered [34]. Although there are some side effects with low percentages, since GLP-1 is a blood glucose-dependent enzyme without risk of hypoglycemia, and negligible gastrointestinal side effects, they are favorable in the treatment of older patients $[13,17$, 21]. According to our observations, clinicians were preferring this OAD as a second-line treatment (25\% usage of DPP4inh.) after metformin in-home care patients.

GLP-1 is a gastrointestinal hormone that is involved in glucose homeostasis primarily by stimulating glucosedependent insulin release from pancreatic islets, slowing gastric emptying [35], inhibiting post-meal glucagon release, and increasing satiety in the brain, thereby contributing to reduced food intake [36]. GLP-1 agonists are a class of antidiabetic agents that mimics the action of glucagon-like peptide. In this class, both exenatide and liraglutide demonstrate their effects by reducing blood glucose, lowering A1c and resulting in progressive, dosedependent weight loss [21]. These agents well tolerated in elderly patients as much as younger patients with low risk of hypoglycemia when used with metformin [37, 38]. Other than these beneficial effects, they may be associated with nausea, vomiting, diarrhea and pancreatitis [37]. We should also pay attention to weight loss, which may not be desirable in some elderly patients with cachexia [39]. In our study, there were only two patients using these groups of drugs. This low usage may be due to the fear of the side effect that we mentioned before.

The alpha-glucosidase enzyme converts complex polysaccharide carbohydrates into monosaccharides. Thus, its inhibition slows the absorption of glucose and decreases the postprandial blood glucose concentrations. Although Alpha-glucosidase inhibitors have a safety profile with no hypoglycemia risk and any other severe adverse effects, gastrointestinal side effects of flatulence and diarrhea limit their use in older patients [20-22]. 
In our study, the $5 \%$ usage rate seems to be low when compared with other studies, which may be due to their gastrointestinal intolerance in older patients [18].

The sodium-glucose co-transporter 2 (SGLT2) in the proximal tubule is responsible for reabsorbing the filtered glucose load up to $90 \%$ [40]. Its inhibition may lead to lower blood glucose levels. There are some studies available in the literature for older diabetic patients that show the efficacy of SGLT-2 inhibitors with the improvement of glycemic control, body weight and blood pressure [41]. They also have no hypoglycemic effects on the older patients. However, since they may cause volume depletion, increase urinary tract infection, decrease in bone mineral density with a significant increase of fracture and rarely causing diabetic ketoacidosis, these drugs should be used cautiously [41-43]. We have observed that 12 of $256(5 \%)$ homecare patients were using these types of drugs. We thought that these drugs could be used in suitable patients if A1c levels go above target.

Diabetes Canada Clinical Practice Guidelines Expert Committee recommended that insulin regimens in older adults should be individualized [17]. Once-daily basal insulin is a simple way of starting insulin in the elderly. Long-acting, once-daily insulins are effective in patients with preserved pancreatic function, which have advantages of relative lack of hypoglycemia risk and flexibility in the time of administration [22]. Basal bolus injection with a combination of one long-acting insulin and three preprandial rapid-acting insulins mimic physiological insulin secretion. Long term use in elderly patients is inconvenient due to its complexity and high risk of hypoglycemia [43]. Pre-mixed insulin analogues can be administered before or after meals [44] and result in better and more durable control than basal insulins alone [45] but at the expense of more hypoglycemia and higher weight gain [46]. Due to IDF recommendations for elderly people, if oral glucose-lowering agents are contraindicated or not tolerated, a long-acting basal insulin is an alternate option. In addition, if the desired goals cannot be achieved, it is recommended to use mix insulin along with triple OAD [43]. In our study, we found that $58 \%$ of the patients were using insulin and when they were evaluated for the types of insulin, there was no difference among the insulin types in $\mathrm{HbA} 1 \mathrm{c}$ levels $(\mathrm{p}>0.05)$.

\section{Conclusion}

The increase in life expectancy, together with the developing technology, causes a rapid increase in the elderly population in home care patients. Although diabetes is frequently seen in-home care patients, the data regarding glycemic control are minimal. Due to the high levels of $\mathrm{HbA} 1 \mathrm{c}$, especially in patients taking insulin, it should be ensured that insulin injection educations should be reviewed intermittently and closer blood sugar monitoring should be provided. As a result, we think that planning regular visits and personalized treatment with keeping in mind the benefit to risk ratios in diabetic patients is an inevitable part of home health care.

Ethics Committee Approval: This study, which was approved by the ethical board of the Ethics Committee of the Fatih Sultan Mehmet Education and Research Hospital (FSMEAH-28.3.2019- 42).

Conflict of Interest: No conflict of interest was declared by the authors.

Financial Disclosure: The authors declared that this study has received no financial support.

Authorship Contributions: Concept - YS, OG; Design - MS, ZY, OG; Supervision - YS, OG, MS; Materials - SD, OG, MS; Data collection and processing - YS, OG, SD, ZY; Analysis and interpretition - MS, OG, YS, SD; Writing - MS, OG, ZY; Critical rewiev - YS, OG.

\section{REFERENCES}

1. Ünal B, Ergör G, Horasan GD, Kalaça S, Sözmen K. Türkiye kronik hastalıklar ve risk faktörleri sıklığı çalışması. Sağlık Bakanlığı Yayın No: 909. Available at: https://sbu.saglik.gov.tr/Ekutuphane/kitaplar/khrfat.pdf. Accessed Mar 17, 2020.

2. Raghupathi W, Raghupathi V. An Empirical Study of Chronic Diseases in the United States: A Visual Analytics Approach. Int J Environ Res Public Health 2018;15:431. [CrossRef]

3. Jaul E, Barron J. Age-Related Diseases and Clinical and Public Health Implications for the 85 Years Old and Over Population. Front Public Health 2017;5:335. [CrossRef]

4. Umpierrez GE, Pasquel FJ. Management of Inpatient Hyperglycemia and Diabetes in Older Adults. Diabetes Care 2017;40:509-17. [CrossRef]

5. American Diabetes Association. 11. Older Adults: Standards of Medical Care in Diabetes-2018. Diabetes Care 2018;4:S119-25. [CrossRef]

6. Kirkman MS, Briscoe VJ, Clark N, Florez H, Haas LB, Halter JB, et al. Diabetes in older adults. Diabetes Care 2012;35:2650-64. [CrossRef]

7. Satman İ, İmamoğlu Ş, Yilmaz CS, Ayvaz G, Çömlekçi A. Türkiyéde ve Dünyáda diyabet, Türkiye Endokrinoloji ve Metabolizma Derneği Diabetes Mellitus Çalışma ve Eğitim Grubu Raporu. Turkish Journal of Endocrinology and Metabolism 2012;16.

8. Directive on the Procedures and Principles of Home Health Care Services Provided by the Ministry of Health 2010. Available at: https:// www.saglik.gov.tr/TR,11271/saglik-bakanliginca-sunulan-evde-saglik-hizmetlerinin-uygulama-usul-ve-esaslari-hakkinda-yonerge.html. Accessed Mar 17, 2020.

9. O'Reilly CA. Managing the care of patients with Diabetes in the Home Care Setting. Diabetes Spectrum 2005;18:162-6. [CrossRef]

10. Subasi N, Oztek Z. Türkiyede karşılanamayan bir gereksinim: Evde bakım hizmeti. TSK Koruyucu Hekimlik Bülteni 2006;5:19-31.

11. İsik O, Kandemir A, Erisen MA, Fidan C. Evde sağlık hizmeti alan hastaların profili ve sunulan hizmetin değerlendirilmesi. Hacettepe Sağlık İdaresi Dergisi 2016;19:171-86.

12. American Diabetes Association. 6. Glycemic Targets: Standards of 
Medical Care in Diabetes-2019. Diabetes Care 2019;42:S61-70.

13. American Diabetes Association. 12. Older Adults: Standards of Medical Care in Diabetes-2019. Diabetes Care. 2019;42:S139-47. [CrossRef]

14. Huang ES, Liu JY, Moffet HH, John PM, Karter AJ. Glycemic control, complications, and death in older diabetic patients: the diabetes and aging study. Diabetes Care 2011;34:1329-36. [CrossRef]

15. Hamada S, Gulliford MC. Mortality in Individuals Aged 80 and Older with Type 2 Diabetes Mellitus in Relation to Glycosylated Hemoglobin, Blood Pressure, and Total Cholesterol. J Am Geriatr Soc 2016;64:1425-31. [CrossRef]

16. International Diabetes Federation. Managing older people with type 2 diabetes global guideline. Brussels, Belgium: International Diabetes Federation (IDF), 2013. Available at: http://www.idf.org/sites/default/files/IDF-Guideline-for-older-people. Accessed Mar 17, 2020.

17. Diabetes Canada Clinical Practice Guidelines Expert Committee, Meneilly GS, Knip A, Miller DB, Sherifali D, Tessier D, Zahedi A. Diabetes in Older People. Can J Diabetes 2018;42 Suppl 1:S283-95. [CrossRef]

18. Patel B, Oza B, Patel KP, Malhotra SD, Patel VJ. Pattern of antidiabetic drugs use in type-2 diabetic patients in a medicine outpatient clinic of a tertiary care teaching hospital. International Journal of Basic \& Clinical Pharmacology 2013;2:485-91. [CrossRef]

19. Kannan, Arshad, Kumar S. A study on drug utilization of oral hypoglycemic agents in type- 2 diabetic patients. Asian Journal of Pharmaceutical and Clinical Research 2011;4:60-4.

20. LeRoith D, Biessels GJ, Braithwaite SS, Casanueva FF, Draznin B, Halter JB, et al. Treatment of Diabetes in Older Adults: An Endocrine Society* Clinical Practice Guideline. J Clin Endocrinol Metab 2019;104:1520-74. [CrossRef]

21. Kezerle L, Shalev L, Barski L. Treating the elderly diabetic patient: special considerations. Diabetes Metab Syndr Obes 2014;7:391-400.

22. Bajwa SJ, Sehgal V, Kalra S, Baruah MP. Management of diabetes mellitus type-2 in the geriatric population: Current perspectives. J Pharm Bioallied Sci 2014;6:151-7. [CrossRef]

23. Bailey CJ, Turner RC. Metformin. N Engl J Med 1996;334:574-9.

24. Stumvoll M, Nurjhan N, Perriello G, Dailey G, Gerich JE. Metabolic effects of metformin in non-insulin-dependent diabetes mellitus. $\mathrm{N}$ Engl J Med 1995;333:550-4. [CrossRef]

25. Sertbas M, Sertbas Y, Ordu O, Berber E, Ozen B, Ozdemir A. Myocardial injury and acute renal failure associated with lactic acidosis due to suicide attempt with metformin. J Pak Med Assoc 2016;66:223-5.

26. de Jager J, Kooy A, Lehert P, Wulffelé MG, van der Kolk J, Bets D, et al. Long term treatment with metformin in patients with type 2 diabetes and risk of vitamin B-12 deficiency: randomised placebo controlled trial. Version 2. BMJ 2010;340:c2181. [CrossRef]

27. Yki-Järvinen H. Thiazolidinediones. N Engl J Med 2004;351:110618. [CrossRef]

28. Grey A. Skeletal consequences of thiazolidinedione therapy. Osteoporos Int 2008;19:129-37. [CrossRef]

29. Colmers IN, Bowker SL, Majumdar SR, Johnson JA. Use of thiazolidinediones and the risk of bladder cancer among people with type 2 diabetes: a meta-analysis. CMAJ 2012;184:E675-83. [CrossRef]

30. Campbell RK. Rationale for dipeptidyl peptidase 4 inhibitors: a new class of oral agents for the treatment of type 2 diabetes mellitus. Ann Pharmacother 2007;41:51-60. [CrossRef]

31. Buse JB, Bethel MA, Green JB, Stevens SR, Lokhnygina Y, Aschner $\mathrm{P}$, et al; TECOS Study Group. Pancreatic Safety of Sitagliptin in the
TECOS Study. Diabetes Care 2017;40:164-70. [CrossRef]

32. Sarashina A, Sesoko S, Nakashima M, Hayashi N, Taniguchi A, Horie Y, et al. Linagliptin, a dipeptidyl peptidase-4 inhibitor in development for the treatment of type 2 diabetes mellitus: a Phase I, randomized, doubleblind, placebo-controlled trial of single and multiple escalating doses in healthy adult male Japanese subjects. Clin Ther 2010;32:1188-204.

33. Scirica BM, Bhatt DL, Braunwald E, Steg PG, Davidson J, Hirshberg B, et al; SAVOR-TIMI 53 Steering Committee and Investigators. Saxagliptin and cardiovascular outcomes in patients with type 2 diabetes mellitus. N Engl J Med 2013;369:1317-26. [CrossRef]

34. Bergman AJ, Cote J, Yi B, Marbury T, Swan SK, Smith W, et al. Effect of renal insufficiency on the pharmacokinetics of sitagliptin, a dipeptidyl peptidase-4 inhibitor. Diabetes Care 2007;30:1862-4. [CrossRef]

35. Nauck MA, Niedereichholz U, Ettler R, Holst JJ, Orskov C, Ritzel $\mathrm{R}$, et al. Glucagon-like peptide 1 inhibition of gastric emptying outweighs its insulinotropic effects in healthy humans. Am J Physiol 1997;273:E981-8. [CrossRef]

36. Koliaki C, Doupis J. Incretin-based therapy: a powerful and promising weapon in the treatment of type 2 diabetes mellitus. Diabetes Ther 2011;2:101-21. [CrossRef]

37. Bode BW, Brett J, Falahati A, Pratley RE. Comparison of the efficacy and tolerability profile of liraglutide, a once-daily human GLP-1 analog, in patients with type 2 diabetes $\geq 65$ and $<65$ years of age: a pooled analysis from phase III studies. Am J Geriatr Pharmacother 2011;9:423-33. [CrossRef]

38. Meneilly GS, Roy-Duval C, Alawi H, Dailey G, Bellido D, Trescoli C, et al; GetGoal-O Trial Investigators. Lixisenatide Therapy in Older Patients With Type 2 Diabetes Inadequately Controlled on Their Current Antidiabetic Treatment: The GetGoal-O Randomized Trial. Diabetes Care 2017;40:485-93. [CrossRef]

39. Davies MJ, D’Alessio DA, Fradkin J, Kernan WN, Mathieu C, Mingrone G, et al. Management of Hyperglycemia in Type 2 Diabetes, 2018. A Consensus Report by the American Diabetes Association (ADA) and the European Association for the Study of Diabetes (EASD). Diabetes Care 2018;41:2669-701. [CrossRef]

40. Ünlüsoy MC, Akuç S, İnceli Hİ. SGLT2 Inhibitors in the Treatment of Diabetes. FABAD J Pharm Sci 2018;43:157-70.

41. Elmore LK, Baggett S, Kyle JA, Skelley JW. A review of the efficacy and safety of canagliflozin in elderly patients with type 2 diabetes. Consult Pharm 2014;29:335-46. [CrossRef]

42. Bode B, Stenlöf K, Sullivan D, Fung A, Usiskin K. Efficacy and safety of canagliflozin treatment in older subjects with type 2 diabetes mellitus: a randomized trial. Hosp Pract (1995) 2013;41:72-84. [CrossRef]

43. International Diabetes Federation Guideline Development Group. Global guideline for type 2 diabetes. Diabetes Res Clin Pract 2014;104:1-52. [CrossRef]

44. Warren ML, Conway MJ, Klaff LJ, Rosenstock J, Allen E. Postprandial versus preprandial dosing of biphasic insulin aspart in elderly type 2 diabetes patients. Diabetes Res Clin Pract 2004;66:23-9. [CrossRef]

45. Galic E, Vrtovec M, Bozikov V, Schwarzenhofer M, Milicevic Z. The impact of the timing of Humalog Mix25 injections on blood glucose fluctuations in the postprandial period in elderly patients with type 2 diabetes. Med Sci Monit 2005;11:PI87-92.

46. Khamseh ME, Haddad J, Yang W, Zilov A, Bech OM, Hasan MI. Safety and effectiveness of biphasic insulin aspart 30 in different agegroups: a1chieve sub-analysis. Diabetes Ther 2013;4:347-61. [CrossRef] 